\title{
Effect of the superficial treatment in the repair of silorane-based composite aged artificially
}

\author{
Efeito do tratamento superficial no reparo de resina a base de silorano
}

Chaiane Emilia DALAZEN ${ }^{1}$

Mario Alexandre Coelho SINHORETI ${ }^{2}$

Margareth COUTINHO'

\section{ABSTRACT}

\section{Objective}

To evaluate the effects of different surface treatments, in repair bond strength of an aged silorane-based composite.

\section{Methods}

Specimens were made of a silorane-based composite (P90, 3M/ESPE), aged with thermal-cycling (10,000 cycles; 5-55 $\left.{ }^{\circ} \mathrm{C}\right)$ and randomly submitted to different surface treatments (each group $n=24$ ): control group (no repair); group 1 (only application of P90 adhesive); group 2 (diamond bur asperization + P90 adhesive); group 3 (aluminum oxide sandblasting + P90 adhesive) and group 4 (asperization + sandblasting $+P 90$ adhesive). Then the specimens were repaired with the same silorane-based composite and each group randomly subdivided into 2 subgroups: stored in distilled water at $37^{\circ} \mathrm{C}$ for 7 days or submitted to thermal-cycling (5,000 cycles). After aging, the tensile test was carried out. The data was submitted to 2-way analysis of variance (2-way ANOVA).

\section{Results}

The repaired groups aged with oven storage for 7 days did not statistically differ ( $p>0.05)$ from the corresponding groups aged with thermalcycling. The bond strength of the specimens was significantly influenced by the superficial treatment $(p<0.01)$. The highest values of tensile bond strength were found in groups $3(20.76 \pm 4.51 \mathrm{MPa})$ and $4(20.67 \pm 3.96 \mathrm{MPa})$, regardless of aging and repair.

\section{Conclusion}

The repair of silorane-based composite showed to be stable after aging, and the superficial treatment with aluminum oxide sandblasting was the most effective.

Indexing terms: Dental restoration repair. Dental restoration failure. Dental materials. Tensile strength.

\section{RESUMO}

\section{Objetivo}

Avaliar o efeito de diferentes tratamentos de superfície, na resistência de união de reparo em um compósito à base de silorano envelhecido.

\section{Métodos}

Foram confeccionados espécimes de compósito a base de silorano (P90, 3M/ESPE), envelhecidos com termociclagem (10.000 ciclos, 5-55 C) e aleatoriamente submetidos a diferentes tratamentos de superfície (cada grupo $\mathrm{n}=24$ ): grupo controle (sem reparo); grupo 1 (só aplicação do adesivo do P90); grupo 2 (asperização com ponta diamantada + adesivo do P90); grupo 3 (jateamento com óxido de alumínio + adesivo do P90) e grupo 4 (asperização e jateamento + adesivo do P90). Em seguida, os espécimes foram reparados com o mesmo compósito de silorano e cada grupo subdivididos aleatoriamente em 2 subgrupos: armazenados em água destilada à $37^{\circ} \mathrm{C}$ por 7 dias ou submetidos termociclagem (5.000 ciclos). Após o envelhecimento, foi realizado o teste de tração. Os dados foram submetidos à análise de variância a dois fatores (ANOVA 2-way).

\section{Resultados}

Os grupos reparados que foram submetidos ao envelhecimento de 7 dias em estufa não diferiram estatisticamente (p>0,05) dos grupos correspondentes envelhecidos com termociclagem. A resistência de união dos espécimes foi significativamente influenciada pelo tratamento superficial $(p<0,01)$. Os maiores valores de resistência à tração foram encontrados nos grupos $3(20,76 \pm 4,51 \mathrm{MPa})$ e $4(20,67 \pm 3,96 \mathrm{MPa})$, independente do envelhecimento ou do reparo.

\section{Conclusão}

O reparo de compósito à base de silorano se mostrou estável após envelhecimento e o tratamento superficial com jateamento de óxido de alumínio foi o mais efetivo.

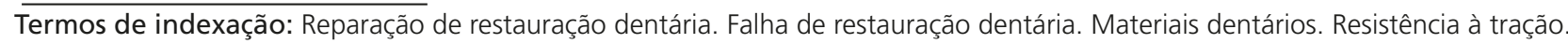

\footnotetext{
${ }^{1}$ Universidade Federal do Mato Grosso do Sul, Faculdade de Odontologia. Cidade Universitária, Caixa Postal 549, 79070-900, Campo Grande, MS, Brasil. Correspondência para / Correspondence to: CE DALAZEN. E-mail:<chaiane_1@msn.com>.

${ }^{2}$ Universidade Estadual de Campinas, Faculdade de Odontologia, Departmento de Dentística Restauradora. Piracicaba, SP, Brasil.
} 


\section{INTRODUCTION}

A new class of composites of low contraction of polymerization, based on a monomer so-called silorane was made available for sale in 2007 . The silorane composite is a hybrid system of monomers deriving from the combination of siloxanes and oxiranes ${ }^{1}$. Considering the properties of these materials, the oxiranes have low polymerization shrinkage because of their reaction of polymerization, where the polymers form through the opening of the cationic rings of the oxirane monomers. The siloxanes account for a higher hydrophobia of the material, and consequently, limit the absorption of water and exogenous pigments ${ }^{1-2}$.

Despite the evolution of composites, failures can occur in the restorations such as the existence of marginal defects, color alterations, deficiency in anatomy, secondary caries and fractures, due to mechanical and chemical degradation, common to any restoration material ${ }^{3-5}$. The correction of these failures, many times, can be done through restoration repair procedure, by removing part of the defective restoration and complementing it with a new composite. The repair is considered a more conservative treatment, for avoiding the enlargement of the cavity preparation and loss of sound dental structure, in addition to be a low cost procedure, require less clinical time and avoid injuries to the pulp tissue $e^{6-9}$.

Different surface treatments have been suggested to increase the mechanical retention, and consequently the bond strength of the repairs, such as diamond bur abrasion ${ }^{10-12}$, abrasion with sandpapers ${ }^{13}$ and sandblasting with aluminum oxide or silica particles ${ }^{12,14-15}$. Bonding agents as adhesives, low viscosity composites and silane can also improve the adaptation of a new resin increment to the asperized surface ${ }^{11,13-14,16-18}$.

The repair of restoration is usually made months or even years after its construction. During this period, the restorative material is exposed to the oral environment conditions, where water absorption and chemical degradation with reduction of free radicals and non-reacted components may occur ${ }^{9,19}$.These alterations, consequence of the restoration's age, may influence on the repair bond strength and must be considered during the laboratory studies ${ }^{20}$.
Although silorane-based composite repair has been investigated in recent studies ${ }^{11-12,16}$, most of these studies did not submit the restoration to aging before repair ${ }^{10-11,14,16,21}$. In literature, there are only a few studies that aged the specimens before the repair and the period of aging in these articles was relatively short, ranging from 3 days to 6 months ${ }^{12-13,18}$. Likely, the analysis of repair stability, after aging, was little investigated in previous studies $^{16}$.

Considering the above discussion, the aim of this study was to evaluate the effect of repair aging of some surface treatments in the repair bond strength of siloranebased composite aged artificially. The first null hypothesis tested was that the surface treatments did not affect the bond strength of silorane-based composite repairs. The second null hypothesis tested was that aging of the repaired specimens reduces bond strength.

\section{METHODS}

\section{Construction of the specimens}

A total of 48 hourglass-shape specimens were made in an addition-cured silicone matrix (Adsil, Vigodent, Rio de Janeiro RJ, Brazil), with $13 \mathrm{~mm}$ length, $2 \mathrm{~mm}$ diameter in the smallest transversal section, $4 \mathrm{~mm}$ diameter in the largest transversal section and $4 \mathrm{~mm}$ width. Increments of $2 \mathrm{~mm}$ of the A2 shade silorane-based composite (Filtek P90, 3M/ESPE) were inserted, and light-cured for $40 \mathrm{~s}$ with the aid of light-curing device (Optilight LD MAX, Gnatus, São Paulo, SP, Brazil), at $800 \mathrm{~mW} / \mathrm{cm}^{2}$ irradiance, verified by using a radiometer.

To standardize the surfaces of these samples, a polyester strip and a glass lamina was placed onto the last layer of composite. Over this set, a 500-g load was applied, for $30 \mathrm{~s}$, enabling the accommodation of the material, and then, light-cured with the bur of the device positioned directly onto the surface of the matrix. Then, they were sectioned in the constriction area, obtaining 96 specimens with a semi-hourglass shape. Still, 12 specimens were made following the same protocol, but with the shape of a complete hourglass. These specimens were not repaired and comprised the control group. All the materials used in this study are presented in Table 1. 
Table 1. Materials used in the present study.

\begin{tabular}{|c|c|c|c|}
\hline Material & Material Composition & Batch & Manufacturer \\
\hline $\begin{array}{l}\text { Filtek }^{\mathrm{TM}} \text { P90- Shades (A2 and } \\
\text { A3) }\end{array}$ & $\begin{array}{l}\text { 3,4-epoxycyclohexylethylcyclopolymethylsiloxane; bis-3,4- } \\
\text { poxycyclohexy } \\
\text { lethylphenylmethylsilane; Silanized quartz; yttrium fluoride; 76wt\% }\end{array}$ & 1204600405 & $\begin{array}{l}\text { 3M ESPE, St. Paul, } \\
\text { MN, USA }\end{array}$ \\
\hline Silorane Bond & $\begin{array}{l}\text { hydrophobic dimethacrylate, phosphorylated methacrylates, } \\
\text { TEGDMA, silane-treated silica filler, initiators, stabilizers }\end{array}$ & 1134700248 & $\begin{array}{l}\text { 3M ESPE, Seefeld, } \\
\text { Baviera Germany }\end{array}$ \\
\hline Aluminum oxide & $50 \mu \mathrm{m}$ aluminum oxide particles & 15651 & $\begin{array}{l}\text { Bio-Art, São } \\
\text { Carlos, SP,Brazil }\end{array}$ \\
\hline $\begin{array}{l}\text { Diamond bur } \\
4138\end{array}$ & $126 \mu \mathrm{m}$ grit Stainless steel and diamond grans. & 10579 & $\begin{array}{l}\text { KG Sorensen, } \\
\text { Cotia, SP, Brazil }\end{array}$ \\
\hline $37 \%$ Phosphoric Acid & 37\% Phosphoric Acid, Thickener, pigment and Deionized Water. & 060911 & $\begin{array}{l}\text { FGM, Joinville, SC } \\
\text { Brazil }\end{array}$ \\
\hline
\end{tabular}

\section{Aging process}

The specimens were submitted to aging through thermal cycling in a thermal cycler (Mycicler Thermalcycler, Bio-Rad, Philadelphia, PA, USA). A total of 10,000 cycles was executed with baths at $55^{\circ} \mathrm{C}, 37^{\circ} \mathrm{C}$ and $5^{\circ} \mathrm{C}$, for 20 s of immersion in each bath.

\section{Surface treatments}

After aging, except for the control group, the specimens were randomly chosen to be submitted to one of the different treatments in the repair surface:

Control Group $(\mathbf{n}=12)$ : The specimens were not repaired.

Bond Group (B) $(\mathbf{n}=\mathbf{2 4})$ : $37 \%$ phosphoric acid etching was carried out for $15 \mathrm{~s}$. Next, the samples were washed for $15 \mathrm{~s}$ and air-jet dried and P90 bond was applied with a disposable brush, followed by light air jet and lightcured for $10 \mathrm{~s}$, according to manufacturer's instruction.

Bur abrasion Group (BA) $(\mathbf{n}=\mathbf{2 4})$ : The specimens were roughened with size \#4138 diamond bur for 20 s, which was applied in only one direction. The diamond bur was replaced after each 15 specimens.

Sandblasting Group (SB) $(\mathbf{n}=\mathbf{2 4})$ : The specimens were sandblasted with $50 \mu \mathrm{m}$ particle aluminum oxide with, for $4 \mathrm{~s}$ at a distance of $10 \mathrm{~mm}$.

\section{Abrasion and Sandblasting Group (BA/SB)}

$\mathbf{( n = 2 4 ) : ~ T h e ~ s p e c i m e n s ~ w e r e ~ r o u g h e n e d ~ w i t h ~ s i z e ~ \# 4 1 3 8 ~}$ diamond bur for 20 s, which was applied in only one direction. The diamond bur was replaced after each 15 specimens. After the roughening the specimens were sandblasted with $50 \mu \mathrm{m}$ particle aluminum oxide, for $4 \mathrm{~s}$ at a distance of $10 \mathrm{~mm}$.

In the specimens of groups 2, 3 and 4, after the superficial treatment, $37 \%$ phosphoric acid etching was executed for 15 s. Following, the samples were washed for $15 \mathrm{~s}$ and air-jet dried, and P90 bond applied with a disposable brush, then air-jet dried and light-cured for 10 $s$, according to manufacturer's instruction.

\section{Specimen repair}

The repair was performed after the treatment of the sample surfaces. The samples were adapted to a silicon matrix with the shape of a complete hourglass with $2.0 \mathrm{~mm}$ diameter in the smallest transversal section, 4.0 $\mathrm{mm}$ diameter in the largest transversal section and 8.0 $\mathrm{mm}$ height. In the remaining space, with a shape of semihourglass the repair of shade A3 composite Filtek P90 was applied. The insertion of the material, on the pre-treated surface, was executed by using increments of up to 2.0 $\mathrm{mm}$ and with the aid of Teflon spatula \# (Hu-Friedy ${ }^{\circledR}$, Chicago, IL, USA). Each increment was light-cured for 40 s. The repair was executed with a composite of different shade from that of the aged specimens, enabling the identification of the interface between the aged and the repair portions.

\section{Additional aging process}

After the repair, the specimens were randomly divided into 2 subgroups $(n=48)$ :

Seven days: Immersion in distilled water at $37^{\circ} \mathrm{C}$ and storage in an oven (Quimis, São Paulo, SP, Brazil), for 7 days.

Thermal cycling: New process of thermal cycling of 5,000 cycles at $5^{\circ} \mathrm{C}, 37^{\circ} \mathrm{C}$ and $55^{\circ} \mathrm{C}$, for $20 \mathrm{~s}$ of immersion for each temperature.

\section{Tensile test and evaluation of the fracture mode}

For the tensile test, the specimens were individually adapted to a stainless steel device with a cavity that enabled the fitting of the samples. The tensile test was executed in a universal testing machine (Instron, Norwood, MA, USA) at $1 \mathrm{~mm} / \mathrm{min}$ crosshead speed, until the moment of rupture. 
After the test, the fracture portions were removed and the fractured area calculated using a digital caliper (Mitutoyo Sul Americana LTDA, Suzano, SP, Brazil).

The fracture strength $(\delta)$ of each specimen was calculated in Mega Pascal (MPa) using the value of rupture force $\mathrm{F}(\mathrm{N})$ and the area $\mathrm{A}\left(\mathrm{mm}^{2}\right)$ of the fractured region: $\delta=F / A$.

The failure mode of each specimen was evaluated with a stereoscopic magnifying glass (Coleman, Santo André, SP, Brazil), with $x 40$ magnification. The type of fracture was classified as: adhesive - when there was the rupture of the bonding interface; cohesive - when there was the rupture of the restorative material; and mixed when the fracture was both adhesive and cohesive.

\section{Statistical analysis}

The values of tensile bond strength in MPa were submitted to two-way analysis of variance (2-way ANOVA) to determine the effects of ${ }^{1}$ aging of the repair and ${ }^{2}$ surface treatment. For the multiple comparisons, Tukey test was applied with level of significance set at $1 \%$. To compare the groups aged for 7 days in an oven with the control group, one-way analysis of variance was applied (one-way ANOVA) followed by Dunnett test with level of significance set at $1 \%$.

\section{RESULTS}

The superficial treatments showed statistically significant effect $(p<0.01)$ on the tensile bond strength (two-way ANOVA). The mean and the standard-deviation values of the tensile bond strength of all the groups are found in table 2. There was no significant interaction $(p=0.966)$ between the superficial treatment and aging, so that the differences among the superficial treatments exhibited the same behavior in both aging procedures.

Table 2. Mean values (MPa) and standard deviations of test groups bond strength.

\begin{tabular}{lcccc}
\hline & B & BA & SB & BA/SB \\
\hline 7 days & $11.79^{b} \pm 1.95$ & $14.50^{b} \pm 1.85$ & $20.76^{\mathrm{a}} \pm 4.51$ & $20.67^{\mathrm{a}} \pm 3.96$ \\
Thermal cycling & $10.56^{\mathrm{b}} \pm 2.03$ & $12.80^{\mathrm{b}} \pm 3.33$ & $18.95^{\mathrm{a}} \pm 4.31$ & $18.43^{\mathrm{a}} \pm 4.29$ \\
\hline
\end{tabular}

Note: Similar superscripts indicate no significant difference between groups ( $p>0.05$, Tukey HSD).

The cohesive strength of P90 material submitted to aging (control group) was 21.31 MPa. Comparing this value with those from the tensile bond strength groups (7 days), we observed that the sandblasting group and the roughened + sandblasting group did not differ statistically ( $p>0.05)$. This demonstrated that these surface treatments maintained compatible values with those of the cohesiveness of the material. However, the comparison of the treatments through the application of the P90 bond with those through diamond bur roughening showed tensile bond strength means significantly smaller $(p<0.01)$ than control group.

The analysis of fracture modes revealed that the fractures were mainly adhesives. Only the groups submitted to the aluminum oxide sandblasting had the highest number of cohesive fractures.

\section{DISCUSSION}

As the caries risk in general has declined, the indication for repair gets even more interesting ${ }^{22}$. Repair is an alternative to the complete replacement of the restoration, especially in cases where the most part of the restoration is considered clinical and radiographically satisfactory. Therefore, it is a more conservative and lower cost treatment. Thus, we investigated the influence of different superficial treatments on the bond strength of silorane-based resin repairs, to establish a protocol of superficial treatment to be executed during clinical practice ensuring adequate bonding.

The specimens evaluated in this present study were aged with 10,000 cycles of thermal cycling, process equivalent to the behavior of composite restoration after 1 year in the oral cavity ${ }^{23}$. The purpose of aging was to simulate the alterations that the restorative material undergoes before repair, because of its exposure to the oral environment conditions. Thermal cycling was chosen because it is a process capable of promoting an accelerated and standardized aging ${ }^{22-25}$. Still, due to lack of information on the adhesive stability of repair ${ }^{12,14}$, this present study simulated a clinical aging of the repaired interface, through 5,000 cycles of thermal cycling, as recommended by the literature $24,26-27$. 
The analysis of the results enabled to verify that the surface treatments ( 7 days in water) behaved similarly to the subgroup submitted to thermal cycling after the repair, without significant statistically differences among them. Therefore, the second hypothesis was rejected and the silorane-based resin repair was stable after aging.

Studies have concluded that the repair bond strength of the composite resin is smaller than the cohesive strength of this material; however, they have also affirmed that this repair bond strength can be considered as clinically acceptable when assuming values higher than 18 $\mathrm{MPa}^{28}$. The results of this present study revealed that the tensile bond strength of the diamond bur abrasion group + application of P90 bond, stored for 7 days in water, were significantly lower than the cohesive strength of the material and it was lower than the values considered as clinically acceptable. Therefore, the superficial treatment influenced on the repair bond strength and the first null hypothesis was rejected. Consequently, although these techniques are of easy execution, they were not enough to ensure adequate bond strength for the silorane-based resin repair.

The tensile bond strength results of the superficial treatment employing the association of aluminum oxide sandblasting with diamond bur abrasion was not better than those of the treatment only with aluminum oxide sandblasting. Therefore, the abrasion before sandblasting did not improve tensile bond strength of the siloranebased composite repair; and so, there is no need to be performed. However, the roughening can occur because of the removal process of the failure part of the restoration ${ }^{11}$, when executed with a diamond bur, and it does not hinder a later aluminum oxide sandblasting.

The groups employing aluminum oxide sandblasting reached higher values of bond strength, indicating the execution of this superficial treatment in the repair procedure. This significantly higher bond strength after the aluminum oxide sandblasting procedure can be the result of the surface topography produced by this treatment. The $50 \mu \mathrm{m}$ particle sandblasting leads to the formation of a more uniform retention mechanical pattern, with higher number of micro-retentions ${ }^{19,22,29}$ and more efficient than the abrasion with diamond bur that exhibits a granulometry higher than $126 \mu \mathrm{m}$ (Figure 1). The characteristics of the roughened and sandblasted surface (BA/SB) are very similar to those of the sandblasted surface (SB), which justifies the similar results between both groups (Figure 1).
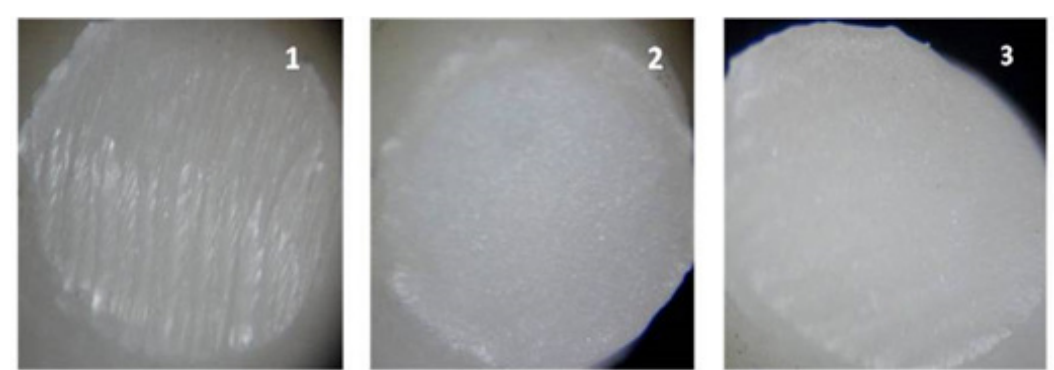

Figure 1. Images of the composite surface after mechanical treatment, obtained with a stereoscopic magnifying glass (40x). Image (1) bur-treated composite surface, image (2) aluminum oxide sandblasted surface and image (3) sandblasted and bur-treated surface.

These results corroborate previous studies concluding that the mechanical embrication is the most important factor for the formation of an adequate bonding interface between the restoration and its repair ${ }^{11,15}$. However, the existing chemical bonding between the old restoration and the repair cannot be forgotten. The execution of the phosphoric acid etching and application of a compatible adhesive system after the mechanical preparation of the surface has increased the repair bond strength ${ }^{13,19,22,30}$. The 35\% phosphoric acid helps to clean the surface, by removing the debris from the mechanical preparation ${ }^{9,11}$. The bond application promotes three bonding mechanisms: chemical bonding to the matrix of the resin; bonding to the filler particles exposed, and micromechanical retention resulting from the penetration of monomers in the irregularities of the resin matrix ${ }^{11,16,18-19,29}$.

The results of the evaluation of the fracture mode in the repaired specimens revealed that the groups presenting better bond strength exhibited a higher number of cohesive fractures. The cohesive fractures better demonstrated the effectiveness of the surface treatment ${ }^{11,30-32}$. On the other hand, we observed that the groups with low bond strength had more adhesive fractures.

Therefore, further studies are necessary and they should evaluate the long-term stability of repair of siloranebased composites. 


\section{CONCLUSION}

The superficial treatment with aluminum oxide sandblasting showed bond strength values similar to those of cohesive strength, and the silorane-based composite repair was stable after aging.

\section{REFERENCES}

1. Weinmann W, Thalacker C, Guggenberger R. Siloranes In Dental Composites. Dent Mater. 2005;21(1):68-74. doi: 10.1016/j. dental.2004.10.007

2. Eick JD, Kotha SP, Chappelow CC, Kilway KV, Giese GJ, Glaros $A G$, et al. Properties Of Silorane-Based Dental Resins And Composites Containing A Stress-Reducing Monomer. Dent Mater. 2007;23(8):1011-7. doi: 10.1016/j.dental.2006.09.002

3. Tezvergil A, Lassila LM, Vallittu PK. Composite-Composite Repair Bond Strength: Effect Of Different Adhesion Primers. J Dent. 2003;31(8):521-5. doi: 10.1016/S0300-5712(03)00093-9

4. Magni E, Ferrari M, Papacchini F, Hickel R, Ilie N. Influence Of Ozone On The Composite-To-Composite Bond. Clin Oral Invest. 2011;15(2):249-56. doi: 10.1007/s00784-009-0370-5

5. Tarumi H, Torii M, Tsuchitani Y. Relationship Between Particle Size Of Barium Glass Filler And Water Sorption Of Light-Cured Composite Resin. Dent Mater. 1995; 14:37-44. doi: 10.4012/ dmj.14.37

6. Gordan VV, Mondragon E, Shen C. Replacement Of Resin-Based Composite: Evaluation Of Cavity Design, Cavity Depth, And Shade Matching. Quintessence Int. 2002 Apr;33(4):273-8.

7. Blum IR, Schriever A, Heidemann D, Mjör IA, Wilson NH. The Repair Of Direct Composite Restorations: An International Survey Of The Teaching Of Operative Techniques And Materials. Eur J Dent Educ. 2003 Feb;7(1):41-8. doi: 10.1034/j.16000579.2003.00275.x

8. Papacchini F, Magni E, Radovic I, Mazzitelli C, Monticelli F, Goracci C, et al. Effect Of Intermediate Agents And Pre-Heating Of Repairing Resin On Composite-Repair Bonds. Operat Dent. 2007;32(4):363-71. doi: http://dx.doi.org/10.2341/06-105

9. Fawzy AS, Ei-Askary FS, Amer MA. Effect Of Surface Treatments On The Tensile Bond Strength Of Repaired Water-Aged Anterior Restorative Micro-Fine Hybrid Resin Composite. J Dent. 2008 Dec;36(12):969-76. doi: 10.1016/j.jdent.2008.07.014.

10. Yaman BC, Efes BG, Dorter C, Gomec Y, Erdilek D, Yazicioglu O. Microleakage Of Repaired Class V Silorane And Nano-Hybrid Composite Restorations After Preparation With Erbium:YttriumAluminum-Garnet Laser And Diamond Bur. Lasers In Med Sci. 2011;26(2):163-70. doi: 10.1007/s10103-010-0755-3.

11. Mobarak EH. Effect Of Surface Roughness And Adhesive System On Repair Potential Of Silorane-Based Resin Composite. J Adv Res [Internet]. 2011.

\section{Collaborators}

Dalazen CE was responsible for executing the research and the writing of the manuscript. Coutinho $M$ and Sinhoreti MAC guided the development of the work and contributed in the writing and revision of the manuscript.

12. Wiegand A, Stawarczyk B, Buchalla W, Tauböck TT, Ozcan M, Attin T. Repair Of Silorane Composite-Using The Same Substrate Or A Methacrylate-Based Composite? Dent Mater. 2012;28(3):E19-25. doi: 10.1016/j.dental.2011.10.008.

13. Maneenut C, Sakoolnamarka R, Tyas MJ. The Repair Potential Of Resin Composite Materials. Dent Mater. 2011;27(2):E20-7. doi: 10.1016/j.dental.2010.09.006

14. Lührs AK, Görmann B, Jacker-Guhr S, Geurtsen W. Repairability Of Dental Siloranes In Vitro. Dent Mater. 2011;27(2):144-9. doi: 10.1016/j.dental.2010.09.009.

15. Brosh T, Pilo R, Bichacho N, Blutstein R. Effect Of Combinations Of Surface Treatments And Bonding Agents On The Bond Strength Of Repaired Composites. J Prost Dent. 1997;77(2):1226. doi:10.1016/S0022-3913(97)70224-5

16. Ivanovas $S$, Hickel R, llie N. How To Repair Fillings Made By Silorane-Based Composites. Clin Oral Investig. 2011;15(6):91522. doi: 10.1007/s00784-010-0473-z.

17. Staxrud F, Dahl JE. Role Of Bonding Agents In The Repair Of Composite Resin Restorations. Eur J Oral Sci. 2011; 119: 316322. doi: 10.1111/j.1600-0722.2011.00833.x.

18. Giachetti L, Russo DS, Baldini M, Goracci C, Ferrari M. Reparability Of Aged Silorane With Methacrylate-Based Resin Composite: Micro-Shear Bond Strength And Scanning Electron Microscopy Evaluation. Oper Dent. 2012;37(1):28-36. doi: 10.2341/10-397L.

19. Rathke A, Tymina $Y$, Haller B. Effect Of Different Surface Treatments On The Composite-Composite Repair Bond Strength. Clin Oral Invest. 2009;13(3):317-23. doi: 10.1007/s00784-0080228-2.

20. Özcan M, Barbosa SH, Melo RM, Galhano GAP, Bottino MA. Effect Of Surface Conditioning Methods On The Microtensile Bond Strength Of Resin Composite To Composite After Aging Conditions. Dent Mater. 2007;23:1276-1282. doi:10.1016/j. dental.2006.11.007

21. Tezvergil-Mutluay A, Lassila LVJ, Vallittu PK. Incremental Layers Bonding Of Silorane Composite: The Initial Bonding Properties. J Dent. 2008 Jul;36(7):560-3. doi: 10.1016/j.jdent.2008.03.008.

22. Gale MS, Darvell BW. Thermal Cycling Procedures For Laboratory Testing Of Dental Restorations. J Dent. 1999;27(2):89-99. doi:10.1016/S0300-5712(98)00037-2

23. Xie C, Han Y, Zhao XY, Wang ZY, He HM. Microtensile Bond Strength Of One- And Two-Step Self-Etching Adhesives On Sclerotic Dentin: The Effects Of Thermocycling. Oper Dent. 2010;35(5):547-55. doi: 10.2341/10-025-L. 
24. Catelan A, Briso AL, Sundfeld RH, Dos Santos PH. Effect Of Artificial Aging On The Roughness And Microhardness Of Sealed Composites. J Esthet Restor Dent. 2010;22(5):324-30 doi: 10.1111/j.1708-8240.2010.00360.x.

25. Price RB, Derand $T$, Andreou P, Murphy D. The Effect Of Two Configuration Factors, Time, And Thermal Cycling On Resin To Dentin Bond Strengths. Biomat. 2003;24(6):1013-21. doi:10.1016/S0142-9612(02)00441-6

26. Bektas O, Eren D, Herguner Siso S, Akin GE. Effect Of Thermocycling On The Bond Strength Of Composite Resin To Bur And Laser Treated Composite Resin. Lasers Med Sci. 2012;27(4):723-8. doi: 10.1007/s10103-011-0958-2.

27. Kashi TSJ, Erfan M, Rakhshan V, Aghabaigi N, Tabatabaei FS. An In Vitro Assessment Of The Effects Of Three Surface Treatments On Repair Bond Strength Of Aged Composites. Operat Dent. 2011c;36(6):608-17. doi: 10.2341/10-386-L.

28. Rodrigues SA, Ferracane JL, Della Bona A. Influence Of Surface Treatments On The Bond Strength Of Repaired Resin Composite Restorative Materials. Dent Mater. 2009;25(4):442-51. doi: 10.1016/j.dental.2008.09.009.
29. Popoff DAV, Santa Rosa TTA, Oliveira WF, Marques IP, Magalhães CS, Moreira NA. Silorane-Based Composite As Repair Material: A Six-Month Randomized Clinical Trial. RGO, Rev Gaúcha Odontol. 2013;61(4):557-563.

30. Ozcan M, Cura C, Brendeke J. Effect Aging Conditions On The Repair Bond Strength Of A Microhybrid And A Nanohybrid Resin Composite. J Adhes Dent. 2010;12(6):451-9. doi: 10.3290/j.jad. a17857.

31. Cehreli SB, Arhun N, Celik C. Amalgam Repair: Quantitative Evaluation of Amalgam-Resin And Resin-Tooth Interfaces Withdifferent Surface Treatments. Oper Dent. 2010;35(3):33744. doi: 10.2341/09-135-L.

32. Blum IR, Lynch CD, Wilson NH. Factors Influencing Repair of Dental Restorations With Resin Composite. Clin Cosmet Investig Dent. 2014;6:81-7. doi: 10.2147/CCIDE.S53461.

Received on: 10/12/2014

Final version resubmitted on: 11/5/2015

Approved on: 23/6/2015 